the following advantages for allowing members to choose to subscribe to the online archive: 1) The plan moves the Association in the anticipated direction of letting members choose the services they want; 2 ) this service would be paid for by those using it; and 3) this option would be an important membership benefit, as only members are to be given the opportunity to purchase access. It was noted that though many members already have access through their academic libraries, not all members do. Those who would like to have online access to past issues of APSR can be served by this option.

\section{William Anderson Award Description Adjusted}

At the request of the Organized Section on Federalism and Intergovernmental Relations President Carol Weissert, the APSA Council approved a slight change in the wording about the purpose of the William Anderson Award, given for the best dissertation in "the field of state and local politics, federalism or intergovernmental relations."

Because of the relatively few nominations for the Anderson award, the Council in 1982 expanded the language from "the field of intergovernmental relations in the United States" to "the field of state and local politics, federalism or intergovernmental relations," language broadening eligibility for the award without fundamentally changing its purpose. The federalism section has in the past asked the Council to revert to the original wording and the Council declined. As an alternative, the section proposed to the Council that the wording of the award's purpose list federalism and intergovernmental relations first, and state and local politics second.

With the Council's approval on April 17, the description of the award will now read: "to honor the best dissertation completed and accepted during the previous two years in the general field of federalism or intergovernmental relations, state and local politics."

\section{Ralph Bunche Summer Institute Participants Selected}

The American Political Science Association is pleased to announce the class for the 1999 Ralph Bunche Summer Institute. The Institute, created to introduce promising upperlevel African American undergraduates to graduate work in political science, is in its thirteenth year of operation and will again be hosted by the University of Virginia. Fifteen outstanding students, representing diverse institutions all over the country, have accepted invitations to participate in this year's Institute.

They are:

Janelle Banks, Smith College

DeAunderia N. Bryant, University of California, Berkeley

Ronnie Booker Jr., University of Virginia

Crystal Curry, Spelman College

Conra Gist, Southwestern University

Christina Grant, Hofstra University

Sacajawea Hall, Goucher College

Lynda Jackson-Sealy, Fairfield University

Lisa Renee Jones, University of Missouri, St. Louis

Berlin Vincent Kelly, Swarthmore College

Tyson Marsh, University of Washington

Jamarlin S. Muhammad, Morehouse College

Alene S. Riley, Prairie View A\&M University

Marcus Lamont Stewart, Mississippi Valley State University

Rickey Williams Jr., Millikin University

The Selection Committee for the 1999 class included Paul Freedman, University of Virginia; Paula McClain, University of Virginia, and chair of the Ralph Bunche Summer Institute; and Maurice Woodard, Howard University and APSA.

The 1999 Institute will be held between June 6 and July 8, 1999.

The Institute is open to African American college students who will have completed their junior year by the start of the Institute. Through their attendance at the institute, students learn the skills they need to become successful graduate scholars.
Attendees take two courses-quantitative analysis and race and American politics - that may qualify for transfer credit, and attend a series of guest lectures given by leading political scientists. Additionally, attendees are given the chance to meet with recruiters from Ph.D. programs and representatives of Educational Testing Service. Many students who attend the Ralph Bunche Summer Institute excel in their senior year and enter graduate political science programs at top schools, often with full fellowships and teaching assistantships.

The Institute is supported by the National Science Foundation, the University of Virginia, and APSA.

For more information, contact Titilayo Ellis, Ralph Bunche Summer Institute, APSA, 1527 New Hampshire Ave., NW, Washington, DC 20036-1206; bunche@apsanet.org; www.apsanet.org/Minority/rbsi.html.

\section{APSA Joins Coalition on Academic Workforce}

With half of new Ph.D.s in political science placed in non-tenure track positions in 1997, APSA should continue its efforts in concert with other scholarly societies to focus on the growing use of part-time, adjunct, and temporary faculty in the U.S., said executive director Catherine Rudder at the April 17 Council meeting. She asked the Council to authorize continuing the work begun at a conference in which APSA participated in September 1997 on the Growing Use of Part-Time and Adjunct Faculty. (See PS [31:668-79] for a report on the conference and www.apsanet.org/Adjunct for the full text of the Council-endorsed conference report.)

Rudder noted that APSA representatives had had an important influence on the content and tenor of the 1997 report and that the Association could continue to play an important role by joining the Coalition on the Academic Workforce that is being formed to implement the recommendations of the 1997 report. The Council unanimously agreed that APSA should join the new coalition. 